\title{
Legal Reasoning Pattern Based On Trancendental Values : A Reflection on Legal Reasoning Based on Positivism Values
}

\author{
Basri \\ Universitas Muhammadiyah Magelang \\ basri@ummgl.ac.id \\ DOI : https://doi.org/10.23917/jtl.v1i1.8694
}

\section{Submission \\ Track: \\ Received: \\ 10 May 2019 \\ Final Revision: 20 June 2019 \\ Available online: 29 June 2019 \\ Corresponding \\ Author: \\ Basri \\ basri@ummgl.ac.id}
Purpose of the study: This article aims at finding out the pattern of legal penalties for transcendental values

Methodology: This research is conducted using descriptive philosophical normative study methods. As a secondary legal material, this writing draws on literature, papers, journals, and research related to this writing.

Main Findings: Positivism-based legal reasoning has failed to accommodate all the interests and legal needs of the community in realizing justice and prosperity. The pattern of legal reasoning based on transcendental values is a choice because it is related to the understanding that places the law for justice and public welfare. Applications of this study: This study can give benefit to thinkers in the field of legal studies thinking to make a breakthrough in the formation of new laws

Novelty/Originality of this study: The use of the basics of transcendental law can be made as a new breakthrough to realize a just and prosperous law

Keywords: Transcendental Law, legal reasoning, positivistic law 


\section{INTRODUCTION}

Talking about the law can not be separated from human, because the law is intended for the benefit of the human. Human has an interest in aspiring and always hoping to get a sense of security, comfort, happiness, and prosperity. One important aspect to be able to achieve and realize the interests, ideals, and expectations of human beings is needed by law based on transcendental values. Until now, legal scholars are still struggling to find what kind of pattern is right about how the law based on transcendental values must be built.

The reality and existence of law nowadays cannot be said to be able to provide a sense of justice and prosperity for society. In fact, on the contrary, the current existence of the law sometimes becomes a problem in life. To the law to provide benefits for justice and welfare, legal thinkers have long struggled to think about what kind of pattern is appropriate as a basis for thinking about the law, so that the law that is built truly benefits human and humanity.

Nowadays, legal reasoning that has a big influence on legal science is positivism. According to Muh. Baqir Sadr, the age of legal reasoning based on positivism is as old as philosophy. However, legal reasoning based on positivism values only developed rapidly in the 19th century, when empiricism dominated thought. So, positivism was born and developed under the auspices of empiricism ${ }^{1}$. The rapid development of positivism-based legal reasoning occurs after the victory of the secularization movement, which seeks to separate strictly between political affairs (state) with Church affairs (religion), and concurrently with the collapse of the authority of the church, which offers a base of transcendental thought. ${ }^{2}$ So, positivism value-based legal reasoning had risen to secularism. In this case, there is a strict separation between political and church matters. Political affairs are managed by the state, while religious matters are managed by the church.

Even though the age of legal thought-based values of positivism has been very old and very influential in the current era, it does not mean that the flow of legal thoughts based on positivism values does not cause problems for the community and are taken for granted by legal thinkers. In fact, the existence of legal reasoning based on the values of positivism has been sued by postpositivistic postmodernism ${ }^{3}$. The legal scholars have doubted the truth of legal reasoning based on the values of positivism because it was considered unable to solve

\footnotetext{
1 Johni Najwan, Implikasi Aliran Posiivisme Terhadap Pemikiran Hukum. Accessed from https://onlinejournal.unja.ac.id/index.php/jimih/article/view/199/176

${ }^{2}$ Ibid.

${ }^{3}$ Absori.2015.Epistimologi Ilmu Hukum Transendental dan Implementasinya dalam Pengembangan Program Doktor Ilmu Hukum. Prosiding Seminar Nasional. ISBN 978-602-72446-0-3.p.35.
} 
the problems of society. The problem in legal reasoning based on positivism values is because of seeing the truth of the measure according to the perception of lawmakers (the law). Whereas lawmakers are based on the willingness of the authorities which is supported by the majority of political groups in the form of laws. Whereas the will and political views of the majority of group do not necessarily reflect the truth. ${ }^{4}$

Legal reasoning based on positivism values has lost an essential element in the form of transcendental values. This is because the way of thinking of supporters of "Reasoning law based on the values of positivism" has separated religious, ethical and moral aspects separate from one unity of civilization development. In their assumption, the world affairs were taken care of by the emperor and religious affairs were left to religious leaders (priests, monks, and ulemas). ${ }^{5}$ Laws are made by putting aside ethical, moral and religious values. So the law is secular, liberal and materialistic. This situation has been certainly very contrary to human nature as a creature that has God, who has a responsibility to others and has a dependency on the Creator.

The legal reasoning system based on positivism values is the worst legal reasoning system. Churaswamy, the UN envoy, gave his condemnation of the Indonesian legal system as one of the worst systems in the world. $^{6}$ This happens because the Indonesian legal reasoning system is based on the values of positivism.

Mochtar Kusumaatmadja ${ }^{7}$ highlighted the problems of the judiciary and the court. According to him, the state of justice and courts in our country is far from satisfactory is well known. In fact, it is a fact that cannot be denied by the court itself.

It is necessary to ponder why law practice is so bad in Indonesia, and so far from what is expected. The law should be able to create justice and prosperity in society. Satjipto Rahardjo $^{8}$ signaled the failure of the operation of the legal system today, including in Indonesia, among others, due to the modern legal system ${ }^{9}$. The modern legal system now dominates and is used in the world, including Indonesia. Modern law is filled with formats and procedures. Modern law is preoccupied with itself rather than with its aim of seeking justice

\footnotetext{
${ }^{4}$ Ibid. P. 36.

${ }^{5}$ Ibid.

${ }^{6}$ Satjipto, Kompas, Saturday, $12^{\text {th }}$ October 2002

${ }^{7}$ Mochtar Kusumaatmadja, 2002. Konsep-konsep Hukum dalam Pembangunan. Bandung: Alumni, p. 182

${ }^{8} \mathrm{Op}$-Cit.

${ }^{9}$ The modern legal system means the form of legal positivism.
} 
Even more than that, Satjipto Rahardjo ${ }^{10}$ described the reality and domination of modern law as a childish period. He said that the Indonesian rule of law needed to be saved from its childish period which is filled with formalities, procedures, and various supporting doctrines. People think by carrying out the formulation of the law (black letter law), the law has been implemented or more than that. This practice will kill the glory and greatness of the law state. A law state should be full of glory and justice.

On the basis of all that it is necessary to find an appropriate pattern of reasoning for the science of law. Lawyers must not stop reviewing legal theories until legal theories that can prosper and be just are found. Related to this, a study of philosophical foundations covering basic beliefs or a world view of the legal system needs to be carried out. Talking about basic belief or world view is talking about a paradigm that gives direction, goal, and implementation/enforcement of national law, so there is no stagnation in law studies in Indonesia.

In this scientific work, writer will try to examine: "The Pattern of Legal Reasoning Based on Transcendental Values", A Reflection on the Reasoning of Law Based on Positivism Values. The issue of legal reasoning based on transcendental values nowadays has become a hot topic and is very important to be discussed. It is very important to be discussed among scholars of law. The emergence of this thought is based on a situation where the existing legal science is not able to present a sense of justice, welfare, and happiness for the community. As a result, there arises a mistrust among people in law and law enforcement. At the same time, a belief emerged that truth and justice have not been sufficiently achieved by formal legal rules. The law is not black and white. The law is to regulate human interests. Therefore, transcendental values cannot be ignored in legal thinking.

\section{RESEARCH METHOD}

This research is conducted by using descriptive philosophical normative study methods. As a secondary legal material, this writing draws on literature, papers, journals, and research related to this writing.

\section{RESULTS \& DISCUSSION}

\section{a. Legal Reasoning Based on Positivism Values}

\footnotetext{
${ }^{10} \mathrm{Op}-\mathrm{Cit}$.
} 
Reasoning is a process of thinking in drawing a conclusion in the form of knowledge. Reasoning produces knowledge that is related to thinking activities. In agreeing to this, think or think about existing knowledge to get other knowledge that didn't exist before. Thus, punishment is an activity that is considered important for the development of human knowledge. ${ }^{11}$. Keraf explains reasoning (way of thinking or reasoning) as: "The process of thinking that seeks to relate facts or evidence relating to conclusions. ${ }^{12}$

Reasoning according to Fadjar Sadiq is a process or a place of thought to draw a conclusion or thought process in the framework of making a new consideration, based on several considerations which their truth has been proven or assumed beforehand. ${ }^{13}$

The pattern of legal reasoning based on the values of positivism was developed from Auguste Comte's theory which was withdrawn from the certainty that there was a law of development that ruled human and all the symptoms of living together and it was absolute. This is what Comte called the Three-Stage Law. According to Auguste Comte, in the ThreeStage Law $^{14}$ there are three stages of development that each society goes through. The first stage is the theological stage. At this stage, human believe in the divine power behind natural phenomena. The second stage is the metaphysical stage. In this stage, a critique of all thoughts, including theological thought, begins. Theological ideas are replaced by abstract ideas from metaphysics. The third stage is the positive stage. In this stage, the phenomena are no longer explained by an abstract natural idea, but the phenomena are explained through other phenomena by discovering the laws between the phenomena concerned. These laws are actually a form of constant relations between these symptoms. So, it can be said that legal reasoning based on the values of positivism is to contain basic values taken from the natural science tradition that places the phenomena studied as objects that can be controlled, and generalized so that future symptoms can be predicted.

With legal reasoning based on the values of positivism, the social sciences have been formed according to rationalism and empiricism of natural science which greatly emphasizes

\footnotetext{
${ }^{11}$ Anonym.1985. Filsafat Ilmu. Jakarta: Universitas Terbuka. P.1

${ }^{12}$ Martin Bernard. 2015. Meningkatkan Kemampuan Komunikasi Dan Penalaran Serta Disposisi Matematik Siswa Smk Dengan Pendekatan Kontekstual Melalui Game Adobe Flash Cs 4.0. Jurnal Infinity. Jurnal Ilmiah Program Studi Matematika STIKP Siliwangi Bandung, Vol. 4, No. 2, September 2015, 197-222.

${ }^{13}$ Herlina Susanti, Hasan Basri Said, Aisyah. 2017, Analisis Kemampuan Penalaran Logis Siswa Yang Memiliki Gaya Berpikir Sekuensial Abstrak Dalam Menyelesaikan Masalah Logika Matematika Kelas Xi Sma Negeri I Tungkal Ulu. PHI: Jurnal Pendidikan Matematik, Vol.1, No.1, 2017.

${ }^{14}$ FX. Adji Samekto, 2012, Menggugat Relasi Filsafat Positivisme Dengan Ajaran Hukum Doktrinal, Jurnal Dinamika Hukum, Vol.12, No.1, January 2012, 7574-8484.
} 
positivistic epistemology. Donny Gahral Adian, stated that positivism institutionalized its objective view in a unified science doctrine. This doctrine states that natural science and social science must be under the umbrella (paradigm) of positivism. The doctrine of the unity of science contains the following criteria for science: ${ }^{15}$ First, free of values; in this case the researcher or observer must be free of interests, values and emotions in observing the object in order to obtain objective knowledge. Second, science must use empirical verification methods. Third, reality is reduced to observable facts.

According to Donny Gahral Adian, positivism-based legal reasoning is a further development of the empiricism ${ }^{16}$ reasoning which believes that reality is everything that is in plain view. In other words, in empiricism, our knowledge must start from empirical verification, more directly based on evidence first. Positivism-based legal reasoning has developed empirical understanding by saying that the peak of human knowledge is positive sciences or sciences that are withdrawn from strictly verified and measurable facts. ${ }^{17}$

According to Boaventura De Sousa Santos, the school of positivism (legal reasoning based on the values of positivism contains basic values taken from the natural science tradition, which places the phenomenon under study as a controllable object and is generalized so that future symptoms can be predicted. ${ }^{18}$ Legal reasoning based on the values of positivism departs from the assumption that natural sciences are the only universally valid science. Based on these assumptions, even though there are differences between natural phenomena and social phenomena, it is considered always possible to study social phenomena with an approach in science nature. The existence of the dominance of the positivism paradigm in natural science which was later adopted in the social sciences led to a way of thinking as if social phenomena must be understood by impersonal, neutral and objective methods, and the "formula" is always the same independent of space and time everywhere.

Based on the explanation above, several teachings in the philosophy of positivism can be explained as follows. First, legal reasoning based on positivism values starts from the view that the philosophy of positivism is based only on reality (reality, facts) and evidence first; second, positivism will not be metaphysical, and does not explain the essence; third, positivism no longer explains natural phenomena as abstract ideas. Natural phenomena are explained on the basis of cause-effect relationships and from this they are obtained by

\footnotetext{
${ }^{15}$ Donny Gahral Adian, 2001, Arus Pemikiran Kontemporer, Jogjakarta: Jalasutra, p. 35-36.

${ }^{16} \mathrm{Ibid}, \mathrm{p}$. 30-31.

${ }^{17}$ Ibid.

${ }^{18}$ FX. Adji Samekto.Op-Cit. P. 8079
} 
propositions or laws that are independent of space and time; fourth, positivism places the phenomenon under study as an object that can be generalized so that in the future it can be predicted (predicted); and fifth, positivism believes that a reality (phenomenon) can be reduced to interrelated elements forming an observable system. ${ }^{19}$

By adopting the way of thinking or legal reasoning based on the values of positivism from Auguste Comte, the legal experts argued that the so-called law must not be abstract, the law must be concrete. This concretization is demonstrated by the necessity that the law must be written. ${ }^{20}$

One of the legal thinker adherents of positivism, HLA Hart said that because the law must be concrete, there must be someone who writes it. Understanding 'who wrote' it refers to the understanding that the law must be issued by a person (subject) who does have the authority to publish and write it. The authority is the state. State authority is indicated by the existence of state attributes, in the form of state sovereignty. Based on its sovereignty, the state is internally authorized to issue and enforce what is called positive law. Furthermore HLA Hart states: first, the law (which has been concretized in the form of positive law) must contain an order; and second, it does not always have to be a link between law and morals and distinguished from the law that should have been created (there is no necessary connection between law and morals or law as it is and law as it ought to be).

As an activity of thinking, reasoning has the following characteristics: (1) As logic. This means that each form of reasoning has its own logic or it can be said that reasoning is a process of logical thinking, where the activities of logical thinking must be interpreted as activities of thinking according to a certain pattern or according to a certain logic; (2) Analytical. This means that reasoning is an activity of thinking that is conscious of itself in an analysis and the frame of mind used for analysis is the logic of reasoning concerned.

To conduct an analysis, the reasoning activity must be filled with material knowledge that is needed from the source of truth. If it is based on ratio or facts, then it is known as understanding rationalism. While they state the facts conveyed through human experience are a source of truth, they develop an understanding of empiricism.

${ }^{19}$ Ibid. $8079-8080$

${ }^{20} \mathrm{Ibid}$. 
Based on the assumption that truth is what can be accepted by reason, the consequence is that the search for truth must take place according to the procedures or laws that have caused the operation of reason. ${ }^{21}$ This is what came to be called logic.

Logic is the law to think right. Logic outlines the rules for thinking right. He studies the conditions that must be met by thought to form the right knowledge, or in other words for a thought to succeed. The application of this logic is known as reasoning. ${ }^{22}$

Generally two models of reasoning are known, namely reasoning with the deductive method and the inductive method. According to Johnson, the deductive method consists of three main steps, namely: First, state the hypothesis (based on theory or research literature); next, collect data to test hypothesis; finally, decide to accept or reject the hypothesis. While the main stages of the inductive method according to Johnson are: first, observe the world; next, search for a pattern in what is observed; and finally, make a generalization about what is occurring. ${ }^{23}$

\section{a. Legal Reasoning Based on Transcendental Values}

The emergence of transcendental legal thinking is as a reaction to the weaknesses and failures of legal reasoning based on the values of positivism, which is unable to solve human and humanitarian problems. Therefore various approaches in the development of science were born.

Absori, Professor of Legal Philosophy at the Faculty of Law, Universitas Muhammadiyah Surakarta, said that there are various paradigms as approaches to the development of science, such as positivism, postpositivism, holistic and transcendental. The transcendental dimension in postmodernism can be seen in a wider range in the form of religion, ethics and morality, which are no longer understood in just one aspect, namely aspects related to theological issues and desires alone, but more than that the question of values can dialogue with issues of scientific, social, cultural, economic and legal development. ${ }^{24}$

In Absori's opinion, the author concludes that the legal reasoning pattern based on transcendental values implies that in developing science, social, cultural, economic, and legal aspects, it cannot be separated from religious, ethical and moral values. The values must be

\footnotetext{
${ }^{21}$ Bambang Sunggono.1998. Metodologi Penelitian Hukum. Jakarta: Raja Grafindo Persada. P. 9.

${ }^{22}$ Khudzaifah Dimyati and Kelik Wardiono. Tt.PEMIKIRAN HUKUM: Sebuah Corak Epistemologi dalam Pemikiran Hukum di Indonesia, Source: https://scholar.google.co.id/scholar?hl=id\&as_sdt=0\%2C5\&q= pemikiran+hukum $+\% 3 \mathrm{~A}+$ Sebuah + Corak + Epistemologi + dalam + Pemikiran + Hukum + di + Indoneisia\&btnG $=$ ${ }^{23}$ Ibid.

${ }^{24}$ Op-cit.
} 
able to be dialogue in the development of science, social, culture, economics, and law. So, religious, ethical, and moral values are integrated into developing science, social, culture, economics, and law.

When compared with legal reasoning based on the values of positivism is very much different, where according to legal reasoning based on the values of positivism science is free from religious values, ethics and morality. Because science is seen as being empirical, objective and logical. Therefore according to Absori, the positivistic paradigm of modern science with the doctrine of empiricism, objectivism, and rationalism began to be sued by postpositivistic postmodernism by putting forward the meaning behind it which became more open and complete. ${ }^{25}$

Furthermore, Absori said that one of the major events in modern science was the end of the Newton era through a revolution and for a long time accepted as a scientific advantage that was able to end its limitations to explain and map nature. Since Newton's new physics and paradigm all of nature is considered to have been seen in an orderly arrangement. But the Newton era is not the end of everything, nature still holds complexities that cannot be explained or reached by Newton's theory. Now Newton's era is replaced by Einstein's Relativity which is better and able to observe complex natural phenomena. New theories about nature, such as modern quantum theory, have changed the view of modern humans who used to assume that something (nature) was clear and certain then changed to undergo deconstruction not only at the physical, reality but also symbolic level. ${ }^{26}$

Postmodernism begins to raise things that are irrational (emotions, feelings, intuition, personal experience, speculation, moral, and spiritual as an integral part of understanding scientific studies/problems. Legal thoughts that are considered unsatisfied (critical even rebellious) against the paradigm of modern law liberal and established categorized as postmodernism thought, the fundamental reason that modern science which has been considered as all things, turns out to be unable to solve the problems of life. The triumph of science is considered to have ended (the end of science). It is no longer useful and is considered unable to solve problems in life of people. Science is considered dominant to interfere in all sectors of life but at the same time science has caused various problems.

According to Absori, legal reasoning based on transcendental values is related to understanding that to place knowledge in a wider range beyond the normative limits of the

\footnotetext{
${ }^{25}$ Delivered in lecturing material, Program S3 Ilmu Hukum UMS, 5/3/2018.

${ }^{26}$ Ibid.
} 
rules of rational science. Scientists place transcendental studies in a metaphysical or supernatural frame of science because they transcend the boundaries of the physical, and spiritual nature. ${ }^{27}$

According to Absori, Immanuel Kant used the term transcendental as understanding beyond the limits of experience. Roger Garaudy interpreted transcendental terms in three perspectives: (1) recognizing human beings' dependence on their creators. An attitude of being self-sufficient by looking at human as the center and the measure of everything is contrary to transcendence. Transcendence overcomes human instincts, such as greed and lust for power. (2) transcendence means recognizing the continuity and common measure between God and man, it means transcendence relieve all power, wealth and knowledge. (3) transcendence means recognizing the superiority of absolute norms that surpass human reason. $^{28}$

Furthermore, Absori said, transcendental thinking can be seen in the values of religion, spiritual, ethics and morality which are full of dynamics and struggles of thoughts that were born in a long span of history. Transcendental thinking begins to elevate things that are irrational and metaphysical (emotions, feelings, intuition, values, personal experience, speculation), moral and spiritual as an integral part of understanding science.

Then based on the theory of emergencies, Absori said that nature is actually uncovered to the top. The nature of consciousness is transcendental, has given a very strong model for the integration between self and spirit. According to Prof. Absori, this is a picture that is exactly the same as what is taught by religion, Judaism, Christianity, and Islam. On this basis, Absori insists that we are now starting seeing a renaissance, a metaphysical (transcendental) revival, from a systematic reflection on the nature and creativity of God.

Furthermore, Absori asserted positivistic may announce that metaphysics (transcendental) has died, however, it seems now positivism has been the first to die. It is very very interesting to see the attention of the era of theism thinkers through dialogue values of Muslims, Jews and Christians who are now re-involved in a very broad exploitation of the idea of "God's hypothesis" and creativity.

Related to law, Absori said, the dialogue of values in the field of law was carried out by discussing them back intensely and profoundly to the conceptual level of the types of law,

\footnotetext{
${ }^{27}$ Absori. 2017. Transendental Hukum Prospek dan Implementasi: Pemikiran Hukum Transendental dalam Konteks Pengembangan Ilmu Hukum Indonesia. Yogyakarta: Genta Publishing. P.14-15.

${ }^{28}$ Ibid.
} 
namely divine nature, revelation, natural law, human nature and behavior, and moral law. $\mathrm{He}$ further emphasized that such activities could prove that there was no longer a need for tension between belief in God and science. The common task we need to endure is to pay attention that trust in God will actually support the results of science, and trust in God is the answer to the fundamental questions raised by scientists, but cannot be answered by it.

By paying attention to Absori's line of thinking, the writer concludes that science must be based on the belief in God and vice versa, science must be able to deliver human to the awareness of God Almighty, which can only be captured by human conscience (metaphysical/transcendent). From this concept the writer wants to conclude that the truth in transcendental thought pattern is truth that is believed to be true, which then logically/rationally can be proven empirically and also according to conscience (naqli) is recognized or not denied its existence. Thus combining faith (faith in the context of Islam), reason and conscience to accept something, the output is truth in the transcendental concept put forward by Absori in the author's perspective. So the base of trampling on truth is faith, reason and heart. So here there is a correlation between religion and science.

In this case it is interesting to follow Bung Hatta's opinion. He wrote, "That's all Albert Einstein!" This assertion states that the mind that creates science must be controlled by a heart that embraces religious feelings, which provides an ethical basis for the use of scientific opinions in the practice of life. The purpose of science must be in line with the purpose of religion, which is to achieve the welfare of humanity. Science is a tool; the goal is physical and spiritual prosperity '. 29

Bung Hatta further explained how the relationship between religion and science was by stating: "Although the fields of religion and real science are separated from each other, there is a strong interrelation and connection between the two. Even though it is religion that sets goals, religion still learns from science in the broadest sense, what tools can help achieve the goals set by people whose souls are full of desires to achieve truth and understanding. And the source of this feeling radiates from the religious field. This area also includes a belief in the possibility that the laws apply to worldly life is rational, that is, reasonable. I could not understand the existence of a great scholar who did not have a deep belief. Its position can be stated that science with no religion is paralyzed, religion with no knowledge of blindness. ${ }^{30}$

\footnotetext{
${ }^{29}$ Endang Saifuddin Anshari. 2004. Wawasan Islam Pokok-Pokok Pikiran Tentang Paradigma Dan Sistem Islam.Jakarta: Gema Insani. P.23-24.

${ }^{30}$ Ibid.28-29.
} 


\section{CONCLUSION}

In closing, the writer concludes that legal reasoning is based on positivistic values with an empirical, objective and logical foundation which is only one element in finding truth. There are other elements that are complementary and very decisive so that the truth is universal, namely the element of faith (belief/religion), and conscience. The element of faith (religion) will lead people to a belief that absolute (irrefutable truth). Therefore human must believe in the truth, for example, belief in the existence of God. The Word of God: Say ye: "We believe in Allah, and the revelation given to us, and to Abraham, Isma'il, Isaac, Jacob, and the Tribes, and that given to Moses and Jesus, and that given to (all) prophets from their Lord: We make no difference between one and another of them: And we bow to Allah (in Islam)." (Al-Baqarah: 136). While the truth according to conscience is the ultimate truth, where the truth is conscience, the deepest heart accept, or cannot reject it. For Indonesia which based on Pancasila, transcendental reasoning patterns are the best solution to the problem of legal justice that has been happening in Indonesia.

\section{REFERENCES}

Absori. 2015. Epistimologi Ilmu Hukum Transendental dan Implementasinya dalam Pengembangan Program Doktor Ilmu Hukum. Prosiding National Seminary. ISBN 978602-72446-0-3 Source: www.google.scholar accessed on 29 $9^{\text {th }}$ May 2018.

Transendental Hukum Prospek dan Implementasi: Pemikiran Hukum

Transendental dalam Konteks Pengembangan Ilmu Hukum Indonesia. Yogyakarta:

Genta Publishing.

Adji Samekto, 2003. Studi Hukum Kritis: Kritik terhadap Hukum Modern, Semarang: Badan Penerbit Universitas Diponegoro.

Anthon F. Susanto. 2010. Ilmu Hukum Non Sistematik Fondasi Filsafat Pengembangan Ilmu Hukum Indonesia. Yogyakarta: Genta Publishing.

Bambang Sunggono.1998. Metodologi Penelitian Hukum. Jakarta: Raja Grafindo Persada.

Donny Gahral Adian, 2001. Arus Pemikiran Kontemporer, Yogyakarta: Jalasutra.

Endang Saifuddin Anshari. 2004. Wawasan Islam Pokok-Pokok Pikiran Tentang Paradigma Dan Sistem Islam.Jakarta: Gema Insani.

FX. Adji Samekto, 2012, Menggugat Relasi Filsafat Positivisme Dengan Ajaran Hukum Doktrinal, Jurnal Dinamika Hukum, Vol.12, No.1, January 2012, 7574-8484 
Herlina Susanti, Hasan Basri Said, Aisyah. 2017, Analisis Kemampuan Penalaran Logis Siswa Yang Memiliki Gaya Berpikir Sekuensial Abstrak Dalam Menyelesaikan Masalah Logika Matematika Kelas Xi Sma Negeri I Tungkal Ulu. PHI: Jurnal Pendidikan Matematik, Vol.1, No.1, Tahun 2017

Johni Najwan, Implikasi Aliran Positivisme Terhadap Pemikiran Hukum. Accessed from https://online-journal.unja.ac.id/index.php/jimih/article/view/199/176

Khudzaifah Dimyati dan Kelik Wardiono. Tt.PEMIKIRAN HUKUM: Sebuah Corak Epistemologi dalam Pemikiran Hukum di Indonesia, Source: https://scholar.google.co.id/scholar?hl=id\&as_sdt=0\%2C5\&q= pemikiran + hukum $+\% 3 \mathrm{~A}+$ Sebuah + Corak + Epistemologi + dalam + Pemikiran + Hukum + di + Indoneisia\&btnG $=$

Martin Bernard. 2015. Meningkatkan Kemampuan Komunikasi Dan Penalaran Serta Disposisi Matematik Siswa Smk Dengan Pendekatan Kontekstual Melalui Game Adobe Flash Cs 4.0. Jurnal Infinity. Jurnal Ilmiah Program Studi Matematika STIKP Siliwangi Bandung, Vol. 4, No. 2, September 2015, 197-222.

Mochtar Kusumaatmadja, 2002. Konsep-konsep Hukum dalam Pembangunan. Bandung: Alumni.

Satjipto, Kompas, Sabtu 12 Oktober 2002

Satjipto Rahardjo, 2003. Ilmu Hukum: Pencarian, Pembebasan dan Pencerahan, Program Doktor llmu Hukum Universitas Diponegoro, Semarang.

Soetandyo, 2002. Hukum: Paradigma, Metode, dan Dinamika Masalahnya, Jakarta: ELSAM, dan HUMA. 